\title{
Pengembangan Modul Mata Kuliah Bahasa Indonesia Di Stmik Stikom Indonesia Berbasis Proyek
}

\author{
Ni Kadek Nita Noviani Pande ${ }^{1}$, Ida Bagus Putrayasa ${ }^{2}$, I Made Sutama ${ }^{3}$ \\ ${ }^{1}$ Teknik Informatika, STMIK STIKOM Indonesia \\ Email: novy.pande@stiki-indonesia.ac.id \\ ${ }^{2}$ Pendidikan Bahasa, Universitas Pendidikan Ganesha \\ ${ }^{3}$ Pendidikan Bahasa, Universitas Pendidikan Ganesha
}

\begin{abstract}
This research is a development research that aims to (1) describe the project-based Indonesian Language module, (2) describe the responses of content experts, module design experts, lecturers, students, and (3) describe the effectiveness of the module seen from student learning outcomes. The test subjects in this study were STMIK STIKOM Indonesia students. Data collection method used is questionnaire. Data were analyzed using qualitative descriptive and quantitative descriptive techniques. The results of the study are 1) project-based Indonesian language print modules, 2) the content expert's response states that the module is well qualified with a percentage level of $88.33 \%$ then module design experts obtain a percentage of $77.5 \%$, the course lecturer states that the module is good to use obtained a percentage of $84.44 \%$ while the test responses of 3 students, 10 students and 30 students showed that the modules obtained percentages of 93.33\%, 83.6\%, and $82.93 \%$, and 3) the effectiveness of project-based subject modules seen from the results Student learning is a significant difference between the average score of student learning outcomes before using project-based modules and after using project-based modules.
\end{abstract}

Keywords : Development, print module, Indonesian Language

\begin{abstract}
Abstrak. Penelitian ini adalah penelitian pengembangan yang bertujuan untuk (1) mendeskripsikan modul mata kuliah Bahasa Indonesia berbasis proyek, (2) mendeskripsikan tanggapan para ahli isi, ahli desain modul, dosen pengampu mata kuliah, mahasiswa, dan (3) mendeskripsikan efektivitas modul di lihat dari hasil belajar mahasiswa. Subjek uji coba dalam penelitian ini adalah mahasiswa STMIK STIKOM Indonesia. Metode pengumpulan data yang digunakan adalah kuesioner. Data di analisis dengan menggunakan teknik deksriptif kualitatif dan deskriptif kuantitatif. Hasil penelitian adalah 1) modul cetak mata kuliah Bahasa Indonesia berbasis proyek, 2) tanggapan ahli isi menyatakan bahwa modul berkualifikasi baik dengan tingkat persentase sebesar $88.33 \%$ kemudian ahli desain modul memperoleh persentase sebesar $77.5 \%$, dosen pengampu mata kuliah menyatakan bahwa modul baik digunakan dengan peroleh persentase sebesar $84.44 \%$ sedangkan tanggapan uji 3 orang mahasiswa, 10 orang mahasiswa dan 30 orang mahasiswa menunjukkan bahwa modul memperoleh persentase masing-masing sebesar 93.33\%, 83.6\%, dan 82.93\%, dan 3) efektivitas modul mata kuliah berbasis proyek dilihat dari hasil belajar mahasiswa adalah terdapat perbedaan yang signifikan antara nilai rata-rata hasil belajar mahasiswa sebelum menggunakan modul berbasis proyek dan setelah menggunakan modul berbasis proyek
\end{abstract}

Kata Kunci : Pengembangan, Modul Cetak, Bahasa Indonesia

\section{PENDAHULUAN}

Pendidikan adalah suatu yang sangat esensial dalam dunia ini. Dengan pendidikan, seseorang dapat mengembangkan potensi yang ada pada dirinya sebagaimana tujuan pendidikan. Dalam Undang-Undang Nomor 20 tahun 2003 tentang Sistem Pendidikan Nasional, Pasal 3, tujuan pendidikan nasional adalah mengembangkan potensi peserta didik agar menjadi manusia yang beriman dan bertakwa kepada Tuhan Yang 
Maha Esa, berakhlak mulia, sehat, berilmu, cakap, kreatif, mandiri, dan menjadi warga negara yang demokratis serta bertanggung jawab.

Dalam konstitusi Negara Republik Indonesia sektor pendidikan tak luput dari perhatian sebagaimana yang tertuang dalam pasal 31 UUD Tahun 1945, ayat 1 'Setiap warga Negara berhak mendapat pendidikan," dan dilanjutkan dalam ayat 2 "pemerintah wajib membiayainya". Hal ini merupakan landasan atau kerangka berfikir tentang sebagaimana pentingnya arti pendidikan bagi suatu Negara, karena pendidikan yang berkualitas sangat memengaruhi maju tidaknya suatu Negara.

Perguruan tinggi merupakan kelanjutan pendidikan menengah yang diselenggarakan untuk mempersiapkan peserta didik menjadi anggota masyarakat yang memiliki kemampuan akademis dan profesional yang dapat menerapkan, mengembangkan dan menciptakan ilmu pengetahuan, teknologi dan kesenian.. Setiap perguruan tinggi membebankan mata kuliah kepada setiap mahasiswa sebagai upaya pemenuhan Satuan Kredit Semester. Mata kuliah tersebut dikelompokkan ke dalam struktur kurikulum perguruan tinggi menjadi lima kelompok yaitu: (1) Kelompok mata kuliah pengemban gan kepribadian (MPK); (2) Kelompok mata kuliah keilmuan dan keterampilan (MKK); (3) Kelompok mata kuliah keahlian berkarya (MKB); (4) Kelompok mata kuliah perilaku berkarya (MPB); (5) Kelompok mata kuliah berkehidupan dan bermasyarakat (MBB). Masing-masing kelompok tersebut memiliki beban SKS atau Satuan Kredit Semester tersendiri yang disesuaikan dan ditentukan oleh masing-masing perguruan tinggi, yang merujuk pada Undang-Undang Nomor 12 Tahun 2012 tentang Pendidikan Tinggi. Tujuan umum penerapan Sistem Kredit Semester di perguruan tinggi di Indonesia agar perguruan tinggi dapat lebih memenuhi tuntutan pembangunan.

Bentuk realisasi kurikulum pada perguruan tinggi adalah diwujudkan melalui kegiatan perkuliahan. Kegiatan perkuliahan adalah proses pembelajaran yang meliputi kegiatan tatap muka di kelas, pratikum, penyelenggaraan percobaan dan pemberian tugas akademik lain. Proses pembelajaran saat ini selalu menekankan betapa pentingnya partisipasi dan aktivitas dari pebelajar. Dengan kegiatan perkuliahan ini, mahasiswa dimungkinkan untuk memilih sendiri mata kuliah yang akan diambil dalam satu semester.

Kenyataan Bahasa Indonesia dijadikan sebagai salah satu mata kuliah Pengembangan Kepribadian tertuang pada SK Mendiknas No.232/U/2000 tentang kurikulum inti dan kurikulum institusional, SK Mendiknas No. 345/U/2002 tentang kompetensi dan SK Dirjen Dikti tentang Mata Kuliah Pengembangan Kepribadian No.43/Dikti/Kep/2006, yang pada intinya kurikulum yang mengembangkan kompetensi dan kepribadian, dan bukan lagi pada penguasaan unsur bahasa. Kompetensi diartikan sebagai perangkat tindakan cerdas, penuh tanggung jawab yang dimiliki seseorang sebagai syarat untuk dianggap mampu oleh masyarakat dalam melaksanakan tugas-tugas dibidang pekerjaan tertentu. Kompetensi juga diartikan sebagai kemampuan yang dimiliki oleh seseorang dalam melaksanakan kegiatan dan pekerjaan.

Visi dari MPK ialah sumber nilai dan pedoman dalam pengembangan dan penyelenggaraan program studi guna mengantarkan para mahasiswa memantapkan kepribadiannya sebagai manusia Indonesia seutuhnya. (Alek A. dan H. Achmad HP, 2010: 6) Misi MPK di perguruan tinggi membantu para mahasiswa memantapkan kepribadiannya agar secara konsisten mampu mewujudkan nilai nilai dasar keagamaan dan kebudayaan, rasa kebangsaan dan cinta tanah air sepanjang hayat dalam menguasai, menerapkan, mengembangkan ilmu pengetahuan, teknologi, dan seni yang dimilikinya dengan rasa tanggung jawab. Dengan demikian, jelaslah bahwa Mata Kuliah Bahasa Indonesia wajib diberikan di perguruan tinggi dengan sebutan Mata Kuliah Pengembangan Kepribadian (MPK) yang bertujuan membekali mahasiswa memiliki kompetensi dan pengembang kepribadian sebagai bangsa Indonesia seutuhnya.

Karakteristik bahasa Indonesia di perguruan tinggi bercirikan berdasarkan kompetensi, komunikatif, terpadu, mengembangkan kepribadian, dan kreativitas. Bahasa Indonesia sebagai sarana komunikasi sekaligus merupakan Mata Kuliah Pengembangan Kepribadian (MPK) bertujuan mengembangkan kompetensi mahasiswa terutama dalam penulisan ilmiah mencakup kemampuan kognitif, afektif, dan psikomotor. Untuk itu, diperlukan bahan-bahan yang memadai untuk mencapai tujuan tersebut. Bahasa juga merupakan sarana untuk mengembangkan menimba ilmu bagi para mahasiswa. Dengan penguasaan bahasa Indonesia yang baik, mahasiswa dapat berkembang menjadi insan yang cerdas, berkepribadian, berkarakter, dan mampu mengembangkan kreativitas baru berdasarkan bidang ilmu, keahlian, dan profesi yang ditekuninya.

Menurut Widjono (2007) substansi mata kuliah bahasa Indonesia mencakup: 1) mata kuliah pengembangan kepribadian menekankan menekankan pada keterampilan berbahasa Indonesia secara baik dan benar untuk menguasai, menerapkan, mengembangkan ilmu pengetahuan teknologi, dan seni sebagai perwujudan kecintaan dan kebanggaan dengan bahasa Indonesia. 2) kajian mencakup kegiatan berbahasa Indonesia melalui keterampilan menyimak, membaca, dan menulis akademik dengan struktur kajian a). kedudukan bahasa Indonesia, b). menulis makalah, rangkuman, ringkasan buku, dan resensi, c). membaca 
untuk internet, d). berbicara untuk keperluan akademik, presentasi, berseminar, dan berpidato dalam situasi formal.

Sebagai mata kuliah pengembangan kepribadian, pembelajaran bahasa Indonesia sangatlah diprioritaskan. Melalui pembelajaran, penguasaan bahasa Indonesia diharapkan dapat mengembangkan berbagai kecerdasan, karakter, dan kepribadian. Orang yang menguasai bahasa Indonesia secara aktif dan pasif akan dapat mengekspresikan pemahaman dan kemampuan dirinya secara runtut, sistematis, logis, da lugas. $\mathrm{Hal}$ ini dapat menandai kemampuan mengorganisasikan karakter dirinya yang terkait dengan potensi daya pikir, emosi, keinginan, dan harapannya yang kemudian diekspresikan dalam berbagai bentuk: artikel, proposal, penulisan laporan, dan sebagainya.

Di sisi lain, orang yang menguasai bahasa Indonesia dengan baik, akan mampu pula memahami konsepkonsep pemikiran, dan pendapat orang lain. Kemampuan ini akan dapat mengembangkan karakter dan kepribadiannya melalui proses berpikir sinergis, yaitu kemampuan menghasilkan konsep baru berdasarkan pengalaman yang sudah dimilikinya bersamaan dengan pengalaman yang baru diperolehnya. Dampaknya, orang yang berkarakter demikian lebih cerdas dan kreatif memanfaatkan stimulus yang diperolehnya.

STMIK STIKOM Indonesia sebagai salah satu perguruan tinggi senantiasa berupaya untuk meningkatkan mutu mahasiswa dari segala aspek sehingga diharapkan nantinya akan memberikan lulusan sarjana yang mempunyai kualitas kompetensi siap bersaing di dunia kerja dan mampu mengembangkan sikap profesional di bidangnya. STMIK STIKOM Indonesia menawarkan Bahasa Indonesia sebagai mata kuliah umum yang termasuk dalam kelompok mata kuliah pengembangan kepribadian (MPK).

Berdasarkan observasi awal yang dilakukan dengan wawancara terhadap beberapa dosen yang mengajar mata kuliah Bahasa Indonesia diperoleh data bahwa masalah penting yang sering dihadapi dosen dalam kegiatan pembelajaran adalah menentukan materi pembelajaran atau bahan ajar yang tepat dalam rangka membantu mahasiswa mencapai kompetensi. Hal ini disebabkan oleh kenyataan bahwa dalam kurikulum atau silabus, materi bahan ajar hanya dituliskan secara garis besar dalam bentuk materi pokok belum adanya sumber ajar ataupun acuan bahan ajar yang dipakai dalam proses perkuliahan mata kuliah ini. Sekalipun ada hanya berpegangan pada Silabus atau materi yang diberikan oleh masing-masing dosen. Tidak ada keseragaman persepsi atau ketidaksepahaman antara dosen satu dengan yang lainnya tentang penyampaian materi kepada mahasiswa. Materi yang disajikan masih bersifat sangat umum dan tidak ada bahan ajar atau modul yang dipakai dalam menyampaikan materi. Hal ini menyebabkan pemahaman mahasiswa akan materi menjadi terbatas dan sulit untuk melakukan pengembangan diri dengan potensi yang dimilikinya. Pola pembelajaran pada mata kuliah Bahasa Indonesia saat ini cenderung bersifat menerima informasi saja (pasif) sehingga kurang menarik perhatian dan tidak mendorong keaktifan mahasiswa dalam belajar, menggali dan membangun pengetahuan. Ditinjau dari sisi proses berarti mahasiswa tidak berinteraksi dengan materi secara efektif. Sebagian besar mahasiswa yang mengambil mata kuliah Bahasa Indonesia mengatakan perlu adanya bahan ajar yang mampu menyajikan materi secara komunikatif.

Faktor lain yang diduga memengaruhi selain bahan ajar yang konvensional adalah penyajian materi yang kurang menghubungkan pengetahuan formal dengan pengalaman mahasiswa sehari-hari, sehingga mahasiswa berpendapat bahwa mata kuliah bahasa Indonesia hanya dipelajari di kampus saja tanpa ada hubungannya dengan kehidupan sehari-hari. Keberadaan bahan ajar atau modul akan membantu pendidik khususnya dosen untuk mencapai tujuan pembelajaran dan memenuhi kompetensi dasar. Penerapan modul dapat menyediakan kegiatan pembelajaran lebih terencana dengan baik, mandiri, tuntas dan dengan hasil (output) yang jelas. Modul dapat memfasilitasi peserta didik lebih tertarik dalam belajar, peserta didik otomatis belajar bertolak dari prerequisites dan dapat meningkatkan hasil belajar (Depdiknas, 2008).

Pengembangan modul dapat menjawab atau memecahkan masalah ataupun kesulitan dalam belajar. Modul dapat dianggap sebagai salah satu faktor yang menentukan kualitas pembelajaran. Modul terbukti efektif dan efisien untuk meningkatkan hasil belajar mahasiswa karena: (1) modul menyajikan deksripsi materi pelajaran yang mudah dimengerti untuk membantu dan memfasilitasi mahasiswa mencapai kompetensi, (2) memberikan kesempatan kepada mahasiswa untuk melakukan praktek kegiatan, sampai mengklarifikasi konsep dengan menunjukkan fakta-fakta. Keuntungan lain yang diperoleh dari pembelajaran dengan penerapan modul adalah sebagai berikut : 1) meningkatkan motivasi peserta didik, karena setiap kali mengerjakan tugas kuliah dibatasi sesuai dengan kemampuan. 2) setelah dilakukan evaluasi, dosen dan mahasiswa mengetahui benar, pada modul yang mana peserta didik telah berhasil dan pada modul yang mana mereka belum berhasil, 3) mahasiswa mencapai hasil sesuai dengan kemampuan mereka masing-masing. 4) bahan mata kuliah terbagi merata dalam satu semester, dan 5) pendidikan lebih berdaya guna, karena materi disusun secara terstruktur. Faktor lain yang diduga memengaruhi rendahnya hasil belajar mahasiswa selain bahan ajar yang konvensional adalah penyajian materi yang kurang menghubungkan pengetahuan formal dengan pengalaman mahasiswa sehari-hari. Dosen juga kurang mampu menyediakan atmosfer belajar yang 
menarik, dan memadai bagi para mahasiswa, karena selama ini dosen hanya mengandalkan metode ceramah dalam proses belajar mengajar. Hal ini, tentu saja kurang dapat merangsang keaktifan dan motivasi mahasiswa dalam belajar.

Salah satu bentuk inovasi pembelajaran mata kuliah Bahasa Indonesia yang dikembangkan dalam penelitian ini adalah pengembangan modul mata kuliah Bahasa Indonesia berbasis proyek (Project Based Learning). Munculnya model pembelajaran berbasis Proyek (Project Based Learning) berangkat dari pandangan konstruktivism yang mengacu pada pembelajaran kontekstual (Dimhad, 2014). Berdasarkan teori belajar konstruktivis dinyatakan bahwa belajar akan lebih bermakna ketika mahasiswa terlibat dalam membangun pengetahuan mereka sendiri. Teori ini menekankan pada penyediaan kesempatan kepada mahasiswa untuk membuat penilaian dan interpretasi dari situasi yang mereka alami sendiri (Hussain, 2012). Salah satu model pembelajaran inovatif yang melibatkan mahasiswa dalam kegiatan pemecahan masalah dan memberi peluang pada mahasiswa untuk bekerja secara otonom mengkonstruksikan cara belajar mereka sendiri, dan puncaknya akan menghasilkan produk yang bernilai dan realistik adalah model pembelajaran berbasis proyek (Buck Institute for Education dalam Al-Tabany, 2014).

Demikian pembelajaran berbasis proyek merupakan model yang menggunakan belajar kontekstual, dimana para mahasiswa berperan aktif untuk memecahkan masalah, mengambil keputusan, meneliti, mempresentasikan, dan membuat dokumen. Pembelajaran berbasis proyek dirancang untuk digunakan pada masalah kompleks yang diperlukan mahasiswa dalam melakukan investigasi dan memahaminya.

Model project based learning (Model Pembelajaran Berbasis Proyek) adalah model pembelajaran yang memberikan kesempatan kepada guru untuk mengelola pembelajaran di kelas dengan melibatkan kerja proyek. Kerja proyek memuat tugas-tugas yang kompleks berdasarkan permasalahan (problem) yang diberikan kepada mahasiswa sebagai langkah awal dalam mengumpulkan dan mengintegrasikan pengetahuan baru berdasarkan pengalamannya dalam beraktivitas secara nyata, dan menuntut mahasiswa untuk melakukan kegiatan merancang, melakukan kegiatan investigasi atau penyelidikan, memecahkan masalah, membuat keputusan, serta memberikan kesempatan kepada mahasiswa untuk bekerja secara mandiri maupun kelompok (kolaboratif).

Berdasarkan pemikiran tersebut, pertimbangan masalah tersebut dianggap perlu untuk mengembangkan modul proyek yang valid, praktis, dan efisien berbasis Bahasa Indonesia dalam kursus bahasa Indonesia di STMIK STIKOM Indonesia sebagai salah satu cara untuk memecahkan masalah pembelajaran. Mengingat selama ini dalam proses pembelajaran masih berpusat pada dosen sehingga siswa menjadi pasif dalam proses pembelajaran dan masih menggunakan metode ceramah sebagai pilihan utama dalam mentransfer ilmu. Situasi ini mempengaruhi rendahnya pemahaman subjek yang diterima siswa.

\section{METODE PENELITIAN}

Model pengembangan yang digunakan dalam pengembangan modul ini adalah ADDIE. Pemilihan model ini didasari atas beberapa pertimbangan. Pertama, model ADDIE disajikan secara sederhana dan sistematik. Tahap-tahapan dalam model ini sudah sangat sederhana jika dibandingkan dengan model desain yang lainnya. Sifatnya yang sederhana dan terstruktur dengan sistematis, membuat model ADDIE sangat mudah dipelajari oleh pengembang. Kedua, model ADDIE relevan dalam pengembangan sebuah modul (Nasohah et al, 2015). Ketiga, hasil penelitian menunjukkan bahwa pengembangan dengan menggunakan model ADDIE, menghasilkan produk dan pembelajaran yang berkualitas.

Seperti yang dikemukakan Martins, Hoskins, Brooks, dan Bennett (2013) bahwa produk modul yang dikembangkan dengan model ADDIE hasilnya terbukti bermanfaat dan dapat meningkatkan hasil belajar siswa. Hal sama dikemukakan oleh Azimi, Ahmadigol dan Rastegarpour (2015), siswa yang dilatih dengan mengikuti model ADDIE memperoleh nilai kinerja yang tinggi dibandingkan dengan metode tradisional. Ini berarti pengembangan produk yang mengikuti langkah-langkah sistematis model ADDIE, menuntun pengembang untuk menciptakan produk yang berkualitas dan bermanfaat. Model ADDIE terdiri atas 5 (lima) langkah, yaitu: (1) analisis (analyze), (2) perancangan (design), (3) pengembangan (development), (4) implementasi (implementation) dan (5) evaluasi (evaluation). Ringkasan kegiatan penelitian pengembangan divisualisasikan pada Gambar 1.

\section{Analisis (Analysis)}

Pada tahap awal dilakukan analisis bersifat deskriptif yang terdiri dari beberapa kegiatan. Pertama, analisis kurikulum. Kegiatan ini dilakukan untuk mengetahui kebutuhan yang diperlukan mata kuliah yang dijadikan sebagai objek pengembangan. Kegiatan analisis kurikulum dilakukan melalui studi lapangan dan studi 
literatur. Studi literatur dengan cara melakukan kajian teori melalui buku-buku dan sumber informasi lainya berkaitan dengan multimedia pembelajaran yang akan dikembangkan. Studi lapangan dilakukan untuk mendapatkan informasi mengenai materi yang akan digunakan dalam pengembangan multimedia pembelajaran seperti penelaahan terhadap kurikulum dan keadaan bagaimana penyampaian materi tersebut di lapangan. Tujuan dari tahapan ini untuk mendapatkan indikator, struktur materi, dan tingkatan materi dari mata mata kuliah Bahasa Indonesia. Kedua, analisis mata kuliah Bahasa Indonesia. Melakukan analisis terhadap kompetensi inti, kompetensi dasar, dan indikator hasil belajar berdasarkan struktur silabus mata kuliah. Karakteristik Bahasa Indonesia di perguruan tinggi bercirikan berdasarkan kompetensi, komunikatif, terpadu,mengembangkan kepribadian, dan kreativitas. Bahasa Indonesia sebagai sarana komunikasi sekaligus merupakan Mata Kuliah Pengembangan Kepribadian (MPK) bertujuan mengembangkan kompetensi mahasiswa terutama dalam penulisan ilmiah mencakup kemampuan kognitif, afektif, dan psikomotor. Untuk itu, diperlukan bahan-bahan yang memadai untuk mencapai tujuan tersebut. Ketiga, analisis karakteristik mahasiswa. Menganalisis karakteristik mahasiswa dimaksudkan untuk mengetahui kemampuan dan keunikan mahasiswa secara perseorangan. Karakteristik mahasiswa yang perlu dipertimbangkan misalnya kebiasaan belajar, akses terhadap teknologi dan informasi, serta kondisi ekonomi. Dalam tahap ini data diperoleh melalui wawancara dilakukan kepada mahasiswa, dan dosen. Hasil analisis yang kemudian disebut draft I, digunakan sebagai bahan pertimbangan dalam mengembangkan modul yang disesuaikan dengan kondisi yang ada sebelum dilanjutkan ke tahap berikutnya. Berdasarkan hasil analisis, ditetapkan mata kuliah yang dijadikan objek penelitian adalah mata kuliah Bahasa Indonesia di Kampus STMIK STIKOM Indonesia. Penetapan objek, sampel, dan lokasi penelitian didasarkan atas kondisi yang memungkinkan dilaksanakannya uji coba yaitu ketersediaan bahan ajar sangat minim, sarana dan prasarana cukup memadai dan jumlah sampel dianggap cukup representatif untuk dilaksanakannya uji coba.

\section{Desain (Design)}

Berdasarkan temuan hasil analisis (draft I), tahap selanjutnya yang dilaksanakan adalah menyusun sistematika modul. Kegiatan yang dilakukan adalah mendesain sampul depan dan belakang modul, peta konsep modul tiap bab, sajian materi, rangkuman materi setiap bab, rangkuman materi tiap bab, latihan soal, tugas proyek, rambu-rambu penilaian latihan soal, daftar pustaka dan halaman profil pengembang modul. Tahap desain umum diawali dengan kegiatan mendesain sampul depan dan belakang modul. Kegiatan ini bertujuan untuk memberikan gambaran awal dari modul yang dihasilkan, sehingga pengguna dalam hal ini adalah mahasiswa nantinya tertarik untuk membaca modul ini karena desain halaman depannya dibuat semenarik mungkin. Sampul depan modul bertuliskan judul modul dan tempat modul ini dikembangkan, sedangkan sampul belakang modul berisikan ringkasan dari seluruh bab materi yang dibahas dalam modul ini. Pada setiap awal Bab baru ditampilkan informasi identitas materi disertai dengan kemampuan yang ingin dicapai pada materi tersebut, indikator dan gambaran umum mengenai materi tersebut. Penyajian seperti ini diharapkan dapat menumbuhkan rasa keingintahuan mahasiswa untuk membaca lebih dalam isi modul tersebut. Pada kegiatan desain materi disesuaikan dengan kebutuhan si pebelajar dan dapat mengembangkan kompetensi si pebelajar terutama mencakup kemampuan kognitif, afektif, dan psikomotor. Dalam pemilihan materi ini disesuaikan juga dengan tingkat kecerdasan si pebelajar yang berbeda-beda, tujuannya agar semua pebelajar dapat memahami dengan materi yang disajikan. Kegiatan pemilihan tugas proyek dalam materi modul. ini dikombinasikan dengan model pembelajaran proyek sehingga beberapa materi yang dsampaikan memerlukan tagihan atau tugas sebagai penilaian akhir dari materi tersebut. Adapun tujuan penerapan tugas proyek ini adalah meningkatkan motivasi belajar, meningkatkan prestasi akademik mahasiswa, meningkatkan kooperatif/kemampuan kolaborasi, meningkatkan kemampuan komunikasi, meningkatkan kemampuan mahasiswa mengelola sumber belajar (meningkatkan keterampilan penelitian pustaka), menciptakan suasana belajar yang menyenangkan, meningkatkan kreatifitas mahasiswa. Hasil yang diperoleh dalam tahap desain digunakan sebagai acuan atau garis besar pada tahap selanjutnya yaitu tahap pengembangan (development).

\section{Pengembangan (Development)}

Tahap pengembangan merupakan tahap di mana seluruh komponen yang dibutuhkan dirangkai menjadi suatu kesatuan sesuai dengan fungsinya. Pengembangan dilakukan berdasarkan tahap desain yang telah direncanakan sebelumnya (draft II). Kegiatan yang dilakukan pada tahap pengembangan, akan diuraikan sebagai berikut. Pertama, pengumpulan bahan. Jenis bahan yang dikumpulkan, disesuaikan dengan karakteristik dan kebutuhan materi pembelajaran. Masing-masing materi pokok, disajikan dengan tingkat kesukaran materi. Kedua, pembuatan modul. Pembuatan dilakukan berdasarkan sistematika modul yang telah direncanakan pada tahap desain. Ketiga, distribusi. Tahap distribusi merupakan tahap di mana produk pengembangan yang telah diuji, diperbanyak (direproduksi kembali) dan didistribusikan kepada pengguna 
dalam rangka evaluasi. Keempat, uji coba produk. Pada tahap ini dilakukan pengujian berdasarkan tinjauan dari beberapa ahli antara lain: ahli isi dan ahli desain modul. Data dalam uji coba diperoleh dengan menggunakan instrumen angket untuk mengetahui kualitas modul yang dikembangkan. Hasil uji coba para ahli ini merupakan masukan untuk dilakukannya revisi sehingga pada akhirnya diperoleh produk yang valid. Hasil tahap ini berupa modul berbasis proyek yang kemudian disebut sebagai draft III. Produk yang telah melewati serangkaian uji coba para ahli, selanjutnya dilakukan analisis dan revisi sebelum dilanjutkan ke tahap berikutnya yaitu tahap implementasi (implementation).

\section{Implementasi (Implementation)}

Pada tahap ini, hasil produk yang dikembangkan diterapkan dalam pembelajaran untuk mengetahui pengaruhnya terhadap hasil belajar mahasiswa. Tahap ini terdiri dari tiga kegiatan. Pertama, pengorganisasian lingkungan belajar. Tujuan dari kegiatan ini adalah untuk memastikan bahwa kelas dan fasilitas yang dibutuhkan telah tersedia sebelum dilakukan uji coba lapangan. Langkah ini dilaksanakan untuk membantu mencapai pengiriman pesan (proses pembelajaran) berjalan efektif tanpa masalah apapun. Pengorganisasian lingkungan belajar dilakukan pada ruang kelas perkuliahan Bahasa Indonesia di Kampus STMIK STIKOM Indonesia. Kedua, uji coba produk. Pada tahap ini dilakukan pengujian berdasarkan tinjauan dari beberapa responden, antara lain: (1) uji dosen mata kuliah, (2) 3 (tiga) orang mahasiswa dalam uji coba perorangan, yang terdiri dari 1 orang mahasiswa yang memiliki kemampuan tinggi, 1 orang mahasiswa yang memiliki kemampuan sedang, dan 1 orang mahasiswa yang memiliki kemampuan rendah, dan (3) 6 (enam) orang mahasiswa dalam uji coba kelompok kecil, yang terdiri dari 2 orang mahasiswa yang memiliki kemampuan tinggi, 2 orang mahasiswa yang memiliki kemampuan sedang, dan 2 orang mahasiswa yang memiliki kemampuan rendah. Instrumen yang digunakan adalah angket uji coba dosen mata kuliah, perorangan dan kelompok kecil. Ketiga, uji coba lapangan terbatas. Uji lapangan merupakan evaluasi yang dilakukan terhadap suatu media pembelajaran yang telah selesai dikembangkan tapi masih membutuhkan atau memungkinkan untuk direvisi akhir. Dalam uji coba, menggunakan subjek coba mahasiswa dalam satu kelas. Kelas yang dipilih dalam uji lapangan adalah 30 mahasiswa. Data dalam uji coba tahap kedua ini diperoleh dengan menggunakan instrumen angket uji coba lapangan untuk mengetahui kualitas modul yang dikembangkan serta revisi produk yang harus dilakukan. Pada tahap ini, didapatkan respon dosen dan mahasiswa terkait modul berbasis proyek yang kemudian disebut sebagai draft IV. Saran dan komentar kemudian dianalisis dan direvisi sebelum dilanjutkan ke tahap berikutnya yaitu tahap evaluasi (evaluation).

\section{Evaluasi (Evaluation)}

Hasil tahap sebelumnya yaitu draft IV, kemudian dilakukan evaluasi untuk melihat apakah produk yang dikembangkan berhasil, dan sesuai dengan harapan awal atau tidak. Instrumen yang digunakan adalah tes hasil belajar yang terdiri dari pretest dan posttest. Pretest diberikan sebelum kegiatan perlakuan menggunakan modul berbasis proyek dimulai. Sedangkan posttest diberikan setelah kegiatan perlakuan menggunakan modul berbasis proyek selesai dilaksanakan. Uji coba ini dilakukan bertujuan untuk menganalisis efektivitas produk penelitian dengan melihat perbedaan antara skor pretest dan posttest yang dicapai mahasiswa dalam pembelajaran dengan menggunakan modul berbasis proyek. Hasil evaluasi kemudian di analisis dan di revisi. Hasil revisi menjadi produk akhir, yaitu modul mata kuliah Bahasa Indonesia berbasis proyek yang sudah teruji kelayakannya dan efektivitasnya.

\section{HASIL DAN PEMBAHASAN}

Tahap pengembangan bahan ajar modul mata kuliah Bahasa Indonesia menggunakan model ADDIE terimplementasikan dalam penelitian pengembangan ini terdiri atas beberapa tahap, yaitu: (1) Analysis (analisis) yang meliputi proses: a) analisis kurikulum, b) analisis karakteristik mata kuliah Bahasa Indonesia, c) analisis karakteristik mahasiswa, d) analisis lingkungan belajar, (2) Design (desain) yang meliputi proses: a) membuat strategi instruksional, b) menyusun sistematika modul dan storyboard, (3) Development (pengembangan) yang meliputi proses: a) pengumpulan bahan, b) pembuatan modul, dan c) uji coba ahli, (4) Implementation (implementasi) yang meliputi: a) uji coba dosen pengampu mata kuliah, mahasiswa dalam kelompok besar, dan (5) Evaluation (evaluasi), dilakukan pada keempat tahap sebelumnya yang meliputi uji coba para ahli, guru mata pelajaran, siswa dalam bentuk uji perorangan, uji kelompok kecil, dan uji coba lapangan terbatas, dan uji efektivitas produk.

Bahan ajar yang dikembangkan berupa modul dikemas dalam versi cetak. Mahasiswa saat ini sebagian besar masih memilih versi cetak dengan alasan ketersediaan materi yang lengkap dan kemudahan dalam penggunaan.Pemilihan bentuk penyajian bahan ajar dalam bentuk modul didasari oleh beberapa faktor antara 
lain: (a) bahan ajar disusun secara sistematis sekaligus menarik mencakup isi materi, metode dan evaluasi serta dapat digunakan secara mandiri untuk mencapai kompetensi yang diharapkan, (b) Materi yang disajikan dalam modul memberikan penjelsan secara lengkap tentang defenisi, klasifikasi,prosedur,perbandingan rangkuman dan sebagainya, (c) pemahaman mahasiswa akan materi yang disajikan dibatasi dengan jelas dan sesuai dengan kemampuan. Hal tersebut diperkuat dengan hasil penelitian yang dilakukan Adeel Khalid (2014) dengan judul Text Books: e-book vs print, menyatakan bahwa buku cetak masih unggul diminati oleh para siswa dibandingkan ebook. Hal tersebut ditinjau dari segi ketersediaan biaya, keterbacaan, ketersediaan, dan kemampuan untuk mencatat, berdampak pada lingkungan, kemudahan penggunaan, logistik dan tingkat penggunaan buku dalam mata pelajaran tertentu.

Penelitian serupa membahas tentang penggunaan buku cetak yang dilakukan oleh Yin Zhang berjudul $E$ books Vs Print Books: Readers Choices and Preferences Acros Contaxts mengemukakan e-book belum diposisikan untuk menggantikan buku cetak. Keduanya memiliki atribut dan fungsi berbeda-beda untuk memenuhi kebutuhan membaca orang yang bervariasi menurut situasional, kontekstual dan demografis individu.Penelitian ini menunjukkan kalau tingkat penggunaan e-book tinggi karena dapat diakses konten dimana saja dan kapan saja, namun para pembaca tidak bisa lepas dari buku cetak karena menurut mereka informasi yang didapat dari buku cetak lebih lengkap.Menurut mereka buku cetak memberikan gambaran yang lebih komprehensif dan prediksi yang lebih akurat.

Bahan ajar memiliki unsur inovatif berupa sajian tugas proyek. Proyek menjadi aktivitas utama yang didesain dalam bahan ajar.Penerapan inovasi pembelajaran berupa pemberian tugas proyek pada materi, meningkatkan pemahaman siswa terhadap kompetensi yang diharapkan. Pemilihan model pembelajaran berbasis proyek, didasari oleh beberapa pertimbangan antara lain, (a) Pembelajaran berbasis proyek merupakan salah satu model pembelajaran inovatif yang melibatkan siswa dalam kegiatan pemecahan masalah dan memberi peluang bekerja sama secara otonom mengkonstruksi belajar mereka sendiri; (b) Pendekatan pembelajaran berbasis proyek memberikan alternatif lingkungan belajar otentik di mana memudahkan siswa meningkatkan keterampilan mereka dalam bekerja dan pemecahan masalah secara kolaboratif; (c) Berdasarkan penelitian-penelitian yang telah dilakukan, pembelajaran berbasis proyek terbukti efektif dalam meningkatkan motivasi belajar siswa (Movahedzadeh, et al, 2012; Ilter, 2014), meningkatkan prestasi belajar siswa (Khaliq, Alam \& Mushtaq, 2015), memberi kesempatan kepada siswa untuk mengetahui kelebihan dan kelemahan mereka dan menunjukkan sikap positif terhadap pembelajaran (Wang, Teng, \& Lin, 2015), meningkatkan kemampuan memecahkan masalah dalam berbagai situasi (Movahedzadeh, et al, 2012), memberikan keterampilan kepada siswa untuk belajar secara mandiri (Bagheri,et al, 2013), dan mengembangkan keterampilan berbicara di depan umum melalui presentasi (Wang, Teng, \& Lin, 2015).

Masalah yang diangkat dalam penelitian pengembangan ini adalah terhambatnya proses perkuliahan di STMIK STIKOM Indonesia karena kurangnya minimnya bahan ajar yang digunakan dalam proses pembelajaran hanya berpedoman pada Silabus dan ketidakseragaman pemaparan masing-masing dosen terkait mata kuliah tersebut, kurangnya alokasi waktu yang disediakan, materi kuliah yang masih belum tersusun sesuai dengan tuntutan mata pelajaran, dan dalam proses pembelajaran belum sepenuhnya menggunakan model yang inovatif.

Permasalahan-permasalahan tersebut dapat diatasi dengan mengembangkan modul pembelajaran yang kreatif dan inovatif. Hal ini diharapkan mampu menjadi salah satu solusi yang baik untuk meningkatkan motivasi dan hasil belajar. Tahap pengembangan modul interaktif menggunakan model ADDIE yang terdiri atas beberapa tahap, yaitu: (1) Analysis (analisis), (2) Design (desain), (3) Development (pengembangan), (4) Implementation (implementasi), (5) Evaluation (evaluasi).Kualitas produk yang dihasilkan, ditinjau dari tiga aspek yaitu validitas, kepraktisan, dan keefektifan. Aspek validitas dilihat dari hasil uji coba para ahli. Aspek dilihat diperoleh dari respon guru dan siswa terkait kemudahan penggunaan dan kemenarikan antarmuka produk. Aspek efektif, dilihat dari hasil analisis uji-t.

Hasil tinjauan hasil ahli isi terhadap modul Bahasa Indonesia menunjukkan bahwa, kelayakan isi bahan ajar adalah $88.33 \%$ dengan kualifikasi baik. Hal ini mengandung makna bahwa, materi yang yang disajikan dalam modul layak diberikan kepada mahasiswa.Ada beberapa alasan tercapainya kualitas isi pada kualifikasi baik adalah sebagai berikut. Pertama, penyusunan materi modul merujuk pada artikel maupun buku-buku yang diterbitkan oleh Kementerian Pendidikan dan Kebudayaan Republik Indonesia, sehingga cakupan isi tidak menyimpang dari standar isi mata kuliah Bahasa Indonesia secara nasional.Pemilihan buku didasarkan pada karakteristik indikator pencapaian kompetensi pada tiap Bab. Pemilihan sumber materi juga memperhatikan aspek keterkinian (update to date) sehingga sangat relevan diberikan kepada mahasiswa. Kedua, materi modul disajikan sistematis. Hal ini didasari hasil penelitian Mangen (dalam Tanner, 2014), yang menemukan bahwa fasilitas "paging", dapat mendukung pembaca dalam membangun representasi spasial teks dengan menyediakan isyarat spasial memori teks dan ingatan. Sehingga pembaca akan mengingat apa yang telah 
dibaca sebelumnya. Penyajian isi yang sistematis, mengajak mahasiswa untuk belajar secara bertahap agar tujuan akhir yaitu mampu menerapkan pengetahuannya dapat tercapai secara maksimal.Di samping itu juga materi dalam modul menggunakan pola yang tetap dalam penulisannya. Hal ini dilakukan merujuk pada pendapat yang disampaikan oleh Tompkins (2010), yang menyatakan bahwa siswa lebih mudah mengenali ideide dan informasi-informasi penting ketika mereka memahami pola penulisan dalam penyajian sebuah materi. Ketiga, isi modul disampaikan menggunakan bahasa dalam percakapan sehari-hari.Penulisan yang sederhana dan menarik dapat menimbulkan kesan seolah-olah pengguna berkomunikasi langsung dengan bahan ajar. Selain faktor bahasa, pola penulisan juga berpengaruh terhadap pemahaman bacaan.

Hasil tinjauan hasil ahli desain modul terhadap modul Bahasa Indonesia menunjukkan bahwa kelayakan bahan ajar dari sisi desain modul adalah $77.5 \%$ dengan kualifikasi baik.Ada beberapa alasan sehingga tercapainya kualitas desain modul pada kualifikasi baik ini adalah sebagai berikut. Desain modul sederhana dan mudah diingat yang memudahkan pengguna yaitu mahasiswa dalam mengakses seluruh materi.Modul menggunakan bahasa yang jelas mampu memberikan kejelasan informasi yang disajikan pada setiap Bab. Modul cetak ini dapat dibawa kemana saja sehingga mahasiswa dapat belajar dimana saja tanpa harus di dalam kelas. Modul cetak ini telah disusun berdasarkan komponen-komponen modul seperti yang dikemukan Santyasa (2009), bahwa penyusunan suatu modul harus terdiri dari komponen-komponen modul berikut ini: 1) sasaran pembelajaran; 2) uraian isi pembelajaran; 3) rangkuman; 4) tes; 5) kunci jawaban; 6) umpan balik; dan 7) daftar pustaka. Pada setiap awal Bab baru ditampilkan informasi identitas materi disertai dengan kemampuan yang ingin dicapai pada materi atau indikator dan gambaran umum mengenai materi tersebut.Penyajian seperti ini diharapkan dapat menumbuhkan rasa keingintahuan mahasiswa untuk membaca lebih dalam isi modul tersebut. Halaman kedua modul. Peta konsep atau gambaran secara umum mengenai pokok-pokok materi apa saja yang akan dibahas pada modul tersebut. Halaman sajian materi dibuat seperti tampilan bahan ajar biasanya.Uraian materi diketik dengan menggunakan Microsoft Word dan dipadukan dengan uraian contoh-contoh dari masing-masing materi. Pada akhir pembahasan materi disampaikan rangkuman.Rangkuman berisi pokok-pokok bahasan yang secara garis besar dari materi yang disampaikan. Rangkuman ini berfungsi untuk menyimpulkan hasil uraian dari materi yang disampaikan di setiap Bab. Selain itu terdapat halaman latihan soal dan tugas proyek yang ditujukan kepada pengguna. Latihan soal ini dimaksudkan untuk mengukur tingkat pemahaman mahasiswa terhadap materi ajar yang telah dipelajari. Mahasiswa dihadapi dengan soal uraian atau menelaah suatu kasus tergantung keluasan materi yang dipelajari. Tidak lupa dicantumkan daftar referensi buku, artikel maupun jurnal yang dipakai dalam penyusunan modul ini. Tampilan modul menggunakan kombinasi warna yang sederhana.Gaya, ukuran, spasi dan warna teks yang konsisten.Teks menggunakan jenis huruf yang polos dalam arti huruf tersebut tidak memiliki garis horizontal maupun vertikal pada sudut-sudutnya. Jenis huruf yang digunakan adalah tipe Times New Roman.Tipe Times New Roman dipilih karena tipe huruf yang paling sering digunakan dalam penulisan buku cetak maupun karya ilmiah lainnya.Ukuran teks yang menggunakan ukuran standar sebesar 12 pt. Spasi teks disesuaikan agar baris-baris teks tidak terlalu rapat dan tidak terlalu jauh.Hal ini dimaksudkan untuk memberikan kenyamanan pengguna dalam membaca isi modul.

Berdasarkan hasil uji coba dosen pengampu mata kuliah Bahasa Indonesia, modul memperoleh persentase $84.44 \%$ dengan kualifikasi baik.Tercapainya kualifikasi baik tersebut didasari oleh beberapa faktor.Sajian materi pembelajaran relevan dengan rumusan tujuan pembelajaran yang telah disesuaikan dengan acuan kurikulum terbaru. Hal ini menjadikan ulasan materi yang disampaikan dalam modul sesuai dengan porsinya dan tidak berlebihan. Penilaian dalam modul, proyek merupakan salah satu teknik penilaian yang digunakan.Teknik ini dinilai mampu mendorong pembelajaran yang menyenangkan, kolaboratif, dan meningkatkan prestasi belajar.Ilter (2014) mengungkapkan bahwa prestasi belajar siswa melalui pembelajaran berbasis proyek lebih baik karena siswa secara aktif membangun pengetahuan mereka melalui proyek-proyek. Siswa belajar bertanggung jawab dan aktif membuat keputusan yang tepat.Tidak hanya proyek, modul juga dilengkapi evaluasi dalam bentuk soal latihan untuk mengukur aspek pengetahuan. Modul yang dikembangkan sangat sesuai digunakan di dalam lingkungan kampus maupun di luar lingkungan kampus karena dapat dipelajari secara mandiri.Pembelajaran dengan menggunakan modul ini dapat dilakukan secara klasikal maupun individual (perorangan).

Hasil uji-t menyebutkan bahwa terdapat perbedaan yang signifikan antara nilai rata-rata hasil belajar mahasiswa sebelum menggunakan modul berbasis proyek dan setelah menggunakan modul berbasis proyek. Berdasarkan hasil nilai rata-rata posttest (sebesar 82.90) yang lebih besar dari nilai rata-rata pretest (sebesar 41.8), dapat diketahui bahwa proses pembelajaran mata kuliah Bahasa Indonesia dengan menggunakan modul berbasis proyek dapat meningkatkan hasil belajar mahasiswa STMIK STIKOM Indonesia. Nilai rata-rata hasil belajar mahasiswa pada mata kuliah Bahasa Indonesia di STMIK STIKOM Indonesia adalah sebesar 82.90. Berdasarkan hasil uji-t dua sampel berpasangan (paired sample t-test) menunjukkan bahwa, signifikansi yang 
diperoleh adalah 0.000 kurang dari nilai signifikansi yang telah ditetapkan yaitu 0.05 sehingga $\mathrm{H}_{0}$ ditolak. Ini berarti, terdapat perbedaan yang signifikan antara nilai rata-rata hasil belajar mahasiswa sebelum dan sesudah menggunakan modul Bahasa Indonesia berbasis proyek.

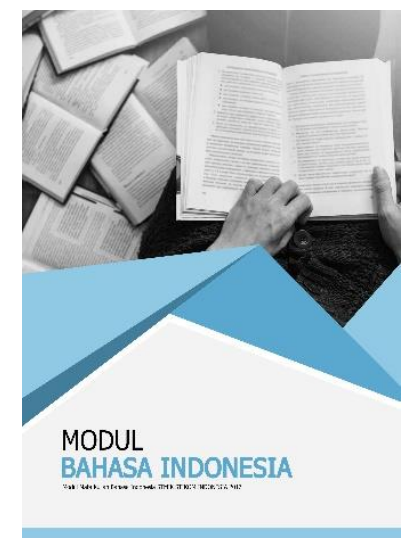

Gambar 1 Sampul Modul

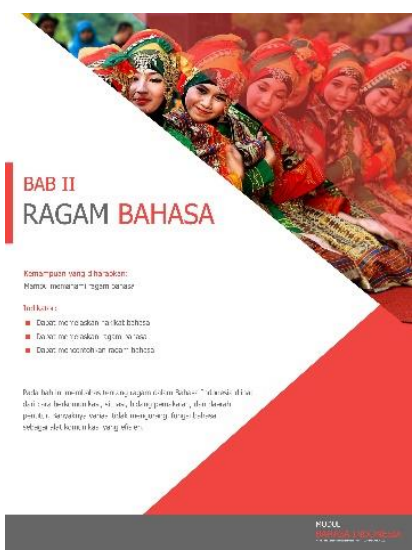

Gambar 2 Tampilan Awal tiap bab

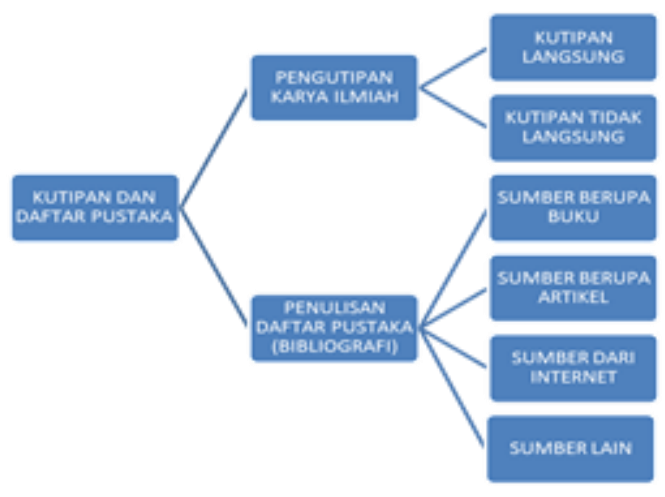

Gambar 3 Peta Konsep tiap bab

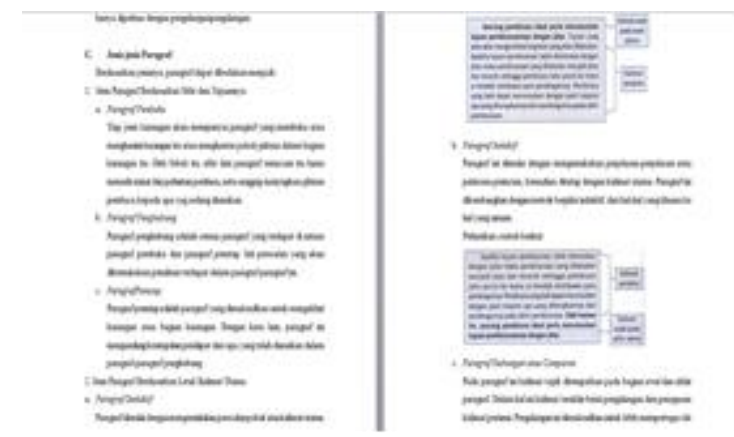

Gambar 4 Materi tiap bab

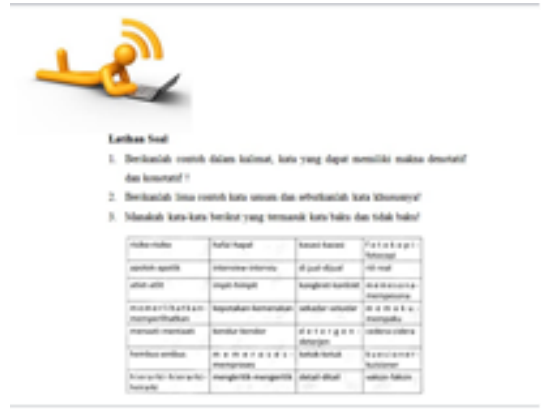

Gambar 5 Latihan soal tiap bab

\section{KESIMPULAN}

Pengembangan modul Bahasa Indonesia berbasis proyek pada mata kuliah Bahasa Indonesia dikembangkan dengan menggunakan model ADDIE yang terdiri atas beberapa tahap, yaitu: (1) Analysis (analisis), (2) Design (desain), (3) Development (pengembangan), (4) Implementation (implementasi), dan (5) Evaluation (evaluasi). Modul yang dikembangkan telah memenuhi aspek validitas, kepraktisan, dan efektivitas. Hasil uji validitas menunjukkan bahwa modul Bahasa Indonesia berbasis proyek berada pada kategori baik berdasarkan uji coba para ahli. Modul Bahasa Indonesia juga telah memenuhi aspek kepraktisan dilihat dari respon dosen pengampu mata kuliah dan mahasiswa terkait kemudahan penggunaannya. Hasil uji-t menunjukkan, terdapat perbedaan yang signifikan antara nilai rata-rata hasil belajar mahasiswa sebelum dan 
setelah menggunakan modul Bahasa Indonesia berbasis proyek. Di mana nilai rata-rata posttest lebih lebih besar dari nilai rata-rata pretest dan telah memenuhi kriteria ketuntasan minimal yang telah ditetapkan. Berdasarkan hal tersebut, modul Bahasa Indonesia berbasis proyek dinilai efektif dalam meningkatkan hasil belajar.

\section{DAFTAR PUSTAKA}

A., Alek dan H. Achmad H.P. 2010.Bahasa Indonesia untuk Perguruan Tinggi. Jakarta: Kencana Prenada Media Group.

Al-Tabany, T. I. B. (2014). Mendesain Model Pembelajaran Inovatif, Progresif, dan Kontekstual - Konsep, Landasan, dan Implementasinya pada Kurikulum 2013 (Kurikulum Tematik Integratif/KTI). Jakarta: Kencana.

Anwar, I. 2010. Pengembangan Bahan Ajar. Bahan Kuliah Online. Direktori UPI. Bandung.

Arifin, Zainal. 2009. Prinsip-prinsip Pembelajaran, dalam Kurikulum dan Pembelajaran. Jurusan Kurikulum dan Teknologi Pendidikan Fakultas Ilmu Pendidikan Universiatas Pendidikan Indonesia: Bandung.

Depdiknas. (2008), Panduan Pengembangan Bahan Ajar

Dimhad. (2014). Penggunaan E-Modul Interaktif Melalui Pembelajaran Berbasis Masalah Untuk Meningkatkan Pemahaman Konsep Sistem Saraf, Kemampuan Generik Sains Dan Berpikir Kritis. http://dimhad13.110mb.com/buku6/a. pdf

Harmer, N. \& Stokes, A. (2014). The benefits and challenges of project-based learning: a review of the literature. (Ed. ke-6). UK: Pedagogic Research Institute and Observatory (PedRIO).

Hussain, I. (2012). Use of constructivist approach in higher education: an instructors' observation. Scientific Research, 3(2), 179-184. Terdapat pada http://file.scirp.org/pdf/CE20120200001_53207289.pdf. Diakses 26 September 2017.

Hs, Widjono. 2007. Bahasa Indonesia. Mata Kuliah Pengembangan Kepribadian di Perguruan Tinggi. Jakarta: Grasindo.

Ilter, I. (2014). A study on the efficacy of project-based learning approach on social studies education: Conceptual achievement and academic motivation. Academic Journals, 9(15). 487-497. Terdapat pada http://www.ijiet.org/ papers/481-S00008.pdf. Diakses 25 Agustus 2017.

Khaliq, S., Alam, M. T., \& Mushtaq, M. (2015). An experimental study to investigate the effectiveness of project-based learning (PBL) for teaching science at elementary level. International Journal of Academic Research in Progressive Education and Development. Terdapat pada http://hrmars.com/hrmars_papers/An_Experimental_Study_to_Investigate_the_Effectiveness_of_Proj ect-Based_Learning_(PBL)_for_Teaching_Science_at_Elementry_Level1.pdf. Diakses 10 Januari 2018.

Khalid, Adeel. 2014. Text Books: ebook Vs. Print. Journal of Education and Human Development. Vol. 3, No. 2, pp. 243-258. American Research Institute for Policy Development.

Kubiatko, M. \& Vaculova, I. (2011). Project-based learning: Characteristic and the experiences with application in the science subjects. Energy Education Science and Technology Part B: Social and Educational Studies, 3(1), 65-74. Terdapat pada http://www.kubiatko.eu/clanky_pdf/project_based_learning.

Martin F., Hoskins, O. J., Brooks, R., \& Bennet, T. (2013). Development of an interactive multimedia instructional module. The Journal of Applied Instructional Design, 3(3), 5-18. Terdapat pada http://www.jaidpub.org/wp-content/uploads/ 2013/12/ MartinEtAl-JAID-Dec2013.pdf. Diakses 18 September 2017.

Movahedzadeh, F., Patwell, R., Rieker, J. E., \& Gonzalez, T. (2012). Project-based learning to promote effective learning in biotechnology courses. Education Research International, 1(1), 1-8. Terdapat pada http://www.hindawi.com/ journals/edri/2012/536024/. Diakses 28 Januari 2016.

Nasohah, U.N., Gani, M. I. B.A., \& Shaid, N. B. M. S. (2015). Model ADDIE dalam proses reka bentuk modul pengajaran: Bahasa Arab tujuan khas di Universiti Sains Islam Malaysia sebagai contoh. Makalah disajikan dalam Proceedings of the International Seminar on Language Teaching tanggal 4-5 Februari 2015, di Bangi - Malaysia.

Sugiyono. 2016. Metode Penelitian Pendidikan. Bandung: Alfabeta.

Tanner, M. J. (2014). Digital vs. print: Reading comprehension and the future of the book. SJSU School of Information Student Research Journal, 4(2), 1-12.Terdapat pada http://scholarworks.sjsu.edu/slissrj/vol4/iss2/6. Diakses 18 Februari 2018.

Tegeh, I M, Jampel, I, N., \& Pudjawan, K. 2014. Model Penelitian Pengembangan. Yogyakarta: Graha Ilmu. 
Tegeh, I. M., dan Kirna, I. M. 2014. Metode Penelitian Pengembangan Pendidikan. Bahan Ajar. Singaraja: Undiksha.

The Geoge Lucas educational Foundation. 2005. Instructional module project learning. http//www.educational.org/modules/PBL/whatpbl.php. Diakses tanggal 27 Agustus 2017.

Tompkins, G. E. (2010). Literacy for the $21^{\text {st }}$ Century - A Balanced Apporach Fifth Edition. Pearson Allyn Bacon Prentice Hall.

Winatha, Redy. 2017. Pengembangan E-modul Interaktif Berbasis Proyek Pada Mata Pelajaran Simulasi Digital Kelas X di SMK TI Bai Global Singaraja. Tesis. Universitas Pendidikan Ganesha.

---------. 2010. Bahasa Indonesia sebagai Mata Kuliah Pengembangan Kepribadian.Tangerang: PT Pustaka Mandiri. 